Both Mr. Richard Perry and Mr. Kenneth Whitehead seem to suggest that the normal ratio in red deer is one big stag to twenty-five other deer. In countries such as the Caucasus, where deer live (or lived) in natural conditions, I never saw more than four hinds with a stag (and seldom that number) in the rutting season. At that moment, of course, young stags would not be allowed near a hind. I believe that the large numbers of hinds seen in Scotland with a master stag is completely unnatural and probably harmful to red deer. At any rate the Caucasian deer make their Scottish cousins look pigmies. I should estimate that a big Caucasian stag weighs forty stone, with a head to match. No doubt leopards, bears, wolves and eagles take a good toll of young deer and there is capital feeding and any amount of covert for the survivors. Moreover their range is practically unlimited and they do not live on an island. They are also amazingly difficult to catch.-Anthony Buxton.

\title{
Lesser Horseshoe Bat in Shropshire
}

I believe Lieut.-Colonel Goodwin to be in error in his statement that his bat from Nash Court, Ludlow, was the first record for the county.

Barrett-Hamilton (in his History of British Mammals, 1910) reported one in the Worcester Museum from Dowles, on the Shropshire side of the Worcester border. This bat is widespread in the Denbighshire limestone areas, and I have ringed specimens in the Ceirog valley within a mile or two of the Shropshire border. Probably the bats are occasionally to be found in immediately adjacent parts of Shropshire.-G. E. HEsketH.

\section{Dormice and Their Diet}

The British native dormouse, Muscardinus avellanarius, has many interesting features; and not the least interesting of these is the question as to whether or not it eats insects. If half a dozen popular natural history books are referred to, it is probable that the result will be confusion. One writer will claim that insects form a substantial part of the food of dormice, another will deny this, while others will be discreetly silent. Where lies the truth?

$I$ have kept many dormice in captivity - in fact I have a pair at the time of writing; and I am always hoping to breed them as I do not think this has ever been done. I have paid much attention to the food preferences of my " sleepy mice", as they are still called in some southern counties, and I am reasonably certain that individual dormice differ in their attitude to 